Jurnal Gizi dan Dietetik Indonesia Vol. 5, No. 1, 2017: 9-16
Tersedia online pada: http://ejournal.almaata.ac.id/index.php/IJND DOI : http://dx.doi.org/10.21927/ijnd.2017.5(1).9-16

\title{
Sifat fisik, kadar serat, dan daya terima naget dengan penggunaan glukomanan dari porang (Amorphophallus oncophyllus) untuk substitusi daging ayam
}

\author{
Dwi Risti Utami ${ }^{1}$, Veriani Aprilia ${ }^{1}$, Fatma Zuhrotun Nisa ${ }^{1}$ \\ ${ }^{1}$ Program Studi S1 IImu Gizi, Fakultas Ilmu-ilmu Kesehatan Universitas Alma Ata Yogyakarta, \\ JI. Brawijaya 99 Yogyakarta \\ 2 Program Studi S1 IImu Gizi, Fakultas Kedokteran, Universitas Gadjah Mada, \\ J. Farmako, Sekip Utara Yogyakarta 55281
}

\begin{abstract}
ABSTRAK
Latar belakang: Penyakit kardiovaskuler merupakan penyebab utama kematian di dunia karena konsumsi kolesterol berlebih. Pengaturan pola makan tinggi serat dapat mengurangi risiko penyakit ini. Naget merupakan produk olahan daging yang banyak digemari masyarakat. Substitusi serat ke dalam naget memiliki fungsi sebagai penurunan kolesterol. Glukomanan porang merupakan serat larut yang merupakan polimer dari mannosa dan glukosa yang diekstraksi dari umbi porang (Amporphophallus oncophyllus). Naget yang disubstitusi glukomanan sebagai serat dapat menjadi alternatif lauk yang bergizi.

Tujuan: Mengetahui pengaruh substitusi glukomanan terhadap sifat fisik (kekenyalan dan water holding capacity/WHC), kadar serat kasar, dan daya terima naget ayam.

Metode: Jenis penelitian ini adalah eksperimental dengan menggunakan RAL. Sampel adalah naget ayam dengan 5 variasi substitusi glukomanan, yaitu naget dengan formula standar (NFS), naget dengan pengurangan daging ayam tanpa substitusi glukomanan porang (NGPO), naget dengan substitusi glukomanan porang 1\% (NGP1), 3\% (NGP3), 5\% (NGP5), dan sebagai pembanding menggunakan substitusi glukomanan konjak 3\% (NGK3). Naget diuji sifat fisik (kekenyalan dan WHC), kadar serat kasar, dan daya terima (sifat organoleptik).

Hasil: Subsitusi glukomanan porang meningkatkan kekenyalan dan WHC, namun kadar serat kasar tidak dipengaruhi. Hasil uji organoleptik membuktikan bahwa substitusi glukomanan hanya mampu diterima sampai kadar 1\%.

Kesimpulan: Substitusi glukomanan berpengaruh terhadap kekenyalan, WHC, dan sifat organoleptik naget ayam.
\end{abstract}

KATA KUNCI: glukomanan, naget ayam, kadar serat kasar, sifat fisik, daya terima

\section{Physical properties, fiber content, and acceptability of nugget with utilization of glucomannan from porang (Amorphophallus oncophyllus) to substitute chicken}

\footnotetext{
ABSTRACT

Background: Cardiovascular disease related with the excess of cholesterol consumption is the leading cause of death in the world. Dietary management of high fiber could decrease the risk of the disease. Nugget is one of favorites meat product. The substitution of fiber within the nugget has the function in lowering the cholesterol. Glucomannan from porang (Amorphophallus oncophyllus) includes in soluble fiber anconsist of mannose and glucose. Nugget substituted with glucomannan shall be the alternative of nutritious food.

Objectives: To evaluate the influence of glucomannan substitution on the physical properties, fiber content, and the acceptability of chicken nugget.

Methods: This was experimental study using random completely design. Samples were chicken nuggets with 5 diferent formula, those were standard (NFS), nugget with the decrease of chicken with porang glucomannan substitution in the percentage of 0\% (NGP0), 1\% (NGP1), 3\% (NGP3), 5\% (NGP5). Nugget with $3 \%$ of konjac glucomannan substitution was used as comparator. Nuggets were then evaluated for their
} 
physical properties (chewiness and water holding capacity/WHC), the content of fiber, and acceptability (organoleptic properties).

Results: The substitution of glucomannan increased the chewiness and WHC, but fiber content was not influenced. Organoleptic results showed that maximum glucomannan concentration that could be added was $1 \%$.

Conclusions: The substitution of glucomannan increased chewines and WHC, but it did not influence the fiber. There was also the decrease in acceptability.

KEYWORDS: glucomannan, fiber content, physical properties, acceptability

\section{PENDAHULUAN}

Menurut WHO (World Health Organization), penyakit kardiovaskuler merupakan penyebab utama kematian di dunia. Pada tahun 2004, sekitar 17,1 juta orang di dunia meninggal karena penyakit kardiovaskuler dan angka tersebut diprediksikan meningkat menjadi sekitar 23,6 juta pada tahun 2030 (1). Faktor risiko utama terjadinya penyakit kardiovaskuler adalah tingginya kadar kolesterol darah (hiperkolesterolemia) yang dapat menyebabkan pembentukan plak di dinding pembuluh darah (aterosklerosis) serta berisiko tiga kali lebih besar terkena serangan jantung. Penurunan $1 \%$ kolesterol darah dapat mengurangi 2-3\% risiko penyakit jantung koroner (sumbatan di pembuluh koroner jantung) (2).

Saat ini, banyak alternatif pengobatan mulai dari obat, herbal, dan pangan fungsional. Pangan fungsional adalah bahan pangan, baik yang berasal dari produk hewani maupun nabati, baik utuh maupun segar, yang mengandung senyawa bioaktif untuk meningkatkan kesehatan seseorang, selain kandungan gizi dan cita rasa yang dimiliki $(2,3)$.

Glukomanan merupakan polimer dari manosa dan glukosa yang dihubungkan oleh ikatan $B-1,4$ (4). Polimer ini dapat digolongkan sebagai pangan fungsional karena terbukti memiliki pengaruh yang baik terhadap kesehatan, salah satunya dapat menurunkan kolesterol total $(5,6)$.

Di Indonesia, glukomanan banyak diekstraksi dari umbi porang (Amporphophallus oncophyllus) dan kadarnya dapat mencapai $64,98 \%$ (7). Glukomanan memiliki sifat kekentalan dan kekenyalan yang tinggi. Menurut Harmayani dkk. (2014) (8), viskositas glukomanan mencapai $5.400 \pm 40,82 \mathrm{cps}$, sehingga glukomanan dapat dimanfaatkan sebagai pengental atau memperbaiki tekstur pada makanan, misalnya dalam pembuatan kue, mie, jeli, roti, es krim, selai, dan jus. Glukomanan yang diekstraksi dari umbi konjak telah banyak diaplikasikan pada produk makanan, namun aplikasi glukomanan yang diekstraksi dari umbi porang masih terbatas.

Naget merupakan produk olahan yang sudah banyak dikenal oleh masyarakat Indonesia dan digunakan sebagai makanan pendamping atau lauk. Naget diolah dari daging giling yang dibumbui, kemudian diselimuti denga perekat tepung, pelumuran tepung roti (breading), dan digoreng setengah matang lalu dibekukan untuk mempertahankan mutunya selama penyimpanan. Naget yang terbuat dari daging ayam memiliki keunggulan kadar kolesterolnya lebih rendah dibandingkan dengan naget yang diolah dari daging sapi. Seperti hasil olahan daging pada umumnya, naget memiliki kelemahan pada kandungan serat yang rendah. Penambahan glukomanan pada naget diharapkan dapat menggantikan sebagian daging karena sifat pengenyal dari glukomanan di samping menambah nilai seratnya. Oleh karena itu, pada penelitian ini akan dikaji pengaruh penambahan glukomanan terhadap kadar serat kasar, sifat fisik, dan daya terima (sifat organoleptik) naget ayam.

\section{BAHAN DAN METODE}

Jenis penelitian ini adalah eksperimental dengan menggunakan rancangan acak lengkap (RAL). Sampel penelitian ini adalah naget ayam dengan 5 variasi substitusi glukomanan, yaitu naget dengan formula standar (NFS), naget dengan pengurangan daging ayam tanpa substitusi glukomanan porang (NGP0), naget dengan substitusi glukomanan porang 1\% (NGP1), $3 \%$ 
(NGP3), 5\% (NGP5), dan sebagai pembanding menggunakan substitusi glukomanan konjak $3 \%$ (NGK3).

Tepung glukomanan diperoleh dari ekstraksi etanol tepung porang menggunakan metode Amanah (1992) (9) dengan sedikit modifikasi. Tepung porang diolah dari umbi porang segar yang dikeringkan, dihaluskan, dan diayak. Umbi porang didapatkan dari Madiun, Jawa Timur. Tepung glukomanan konjak dibeli dari CNLAB Nutrition, Cina. Bahan-bahan untuk membuat naget dibeli dari pasar lokal di Daerah Istimewa Yogyakarta.

Naget dibuat dengan cara mencampurkan daging ayam giling dengan semua bahan sampai rata, ditutup aluminium foil, kemudian dibekukan selama 5 jam. Adonan beku dicetak dan diratakan dengan tepung roti, kemudian digoreng (10). Formula pembuatan naget dapat dilihat pada Tabel 1. Sampel kemudian diuji sifat fisik, nilai gizi, dan daya terimanya. Sifat fisik yang diuji yaitu kekenyalan dan daya ikat air (water holding capacity) (11), sedangkan nilai gizi yang diukur yaitu kadar serat kasar (12). Daya terima naget yang diuji secara organoleptik, meliputi: rasa, aroma, warna, dan tekstur.

\section{HASIL}

\section{Sifat fisik}

\section{Kekenyalan}

Kekenyalan naget ayam dengan beberapa perlakuan dapat dilihat pada Gambar 1.

Naget yang disubstitusi dengan glukomanan porang pada umumnya memiliki kekenyalan yang lebih tinggi dibanding formula standar dan berbeda nyata $(p<0,05)$, kecuali untuk sampel NGP1. Pada tingkat konsentrasi penambahan yang sama, antara naget yang disubstitusi glukomanan konjak (komersial) dengan yang disubstitusi glukomanan porang menunjukkan hasil yang tidak berbeda nyata $(p>0,05)$.

\section{Water holding capacity (WHC)}

Besarnya daya ikat air (water holding capacity) naget ayam pada berbagai variasi susbstitusi glukomanan porang dapat dilihat pada Gambar 2.

Gambar 2 menunjukkan bahwa daya ikat air akan meningkat seiring dengan makin banyaknya glukomanan porang yang ditambahkan, namun hasil uji statistik antara sampel NGP1, NGP3, NGP5, dan NGK3 menunjukkan hasil yang tidak berbeda nyata $(p>0,05)$. Keempat sampel tersebut memiliki nilai yang lebih tinggi dan berbeda nyata dibanding NFS dan NGPO.

\section{Kadar serat kasar}

Berdasarkan Gambar 3, sampel NFS memiliki kadar serat kasar paling tinggi. Pada sampel naget yang disubstitusi glukomanan, kadar serat kasar meningkat dengan bertambahnya jumlah glukomanan porang yang ditambahkan. Namun demikian, hasil uji statistik menunjukkan tidak ada beda signifikan antara NGP0, NGP1, dan NGP3. Hanya NGP5 memiliki kadar serat kasar lebih tinggi dan berbeda nyata dibandingkan dengan NGPO $(p<0,05)$.

Tabel 1. Formula bahan untuk pembuatan naget ayam

\begin{tabular}{lcccccc}
\hline \multirow{2}{*}{ Bahan-bahan } & NFS & NGP0 & NGP1 & NGP3 & NGP5 & NGK3 \\
\cline { 2 - 7 } & 400 & 200 & 200 & 200 & 200 & 200 \\
Daging ayam & 0 & 0 & 2,8 & 8,4 & 14 & 0 \\
Glukomanan porang & 0 & 0 & 0 & 0 & 0 & 8,4 \\
Glukomanan konjak & 20 & 20 & 20 & 20 & 20 & 20 \\
Tepung tapioka & 20 & 20 & 20 & 20 & 20 & 20 \\
Tepung high gluten & 40 & 40 & 40 & 40 & 40 & 40 \\
Susu skim & 4 & 4 & 4 & 4 & 4 & 4 \\
Bawang putih & 2,5 & 2,5 & 2,5 & 2,5 & 2,5 & 2,5 \\
Bawang merah & 6 & 6 & 6 & 6 & 6 & 6 \\
Garam & 4 & 4 & 4 & 4 & 4 & 4 \\
Merica halus & 2 & 2 & 2 & 2 & 2 & 2 \\
Penyedap & 3,5 & 3,5 & 3,5 & 3,5 & 3,5 & 3,5 \\
Gula & & & & &
\end{tabular}




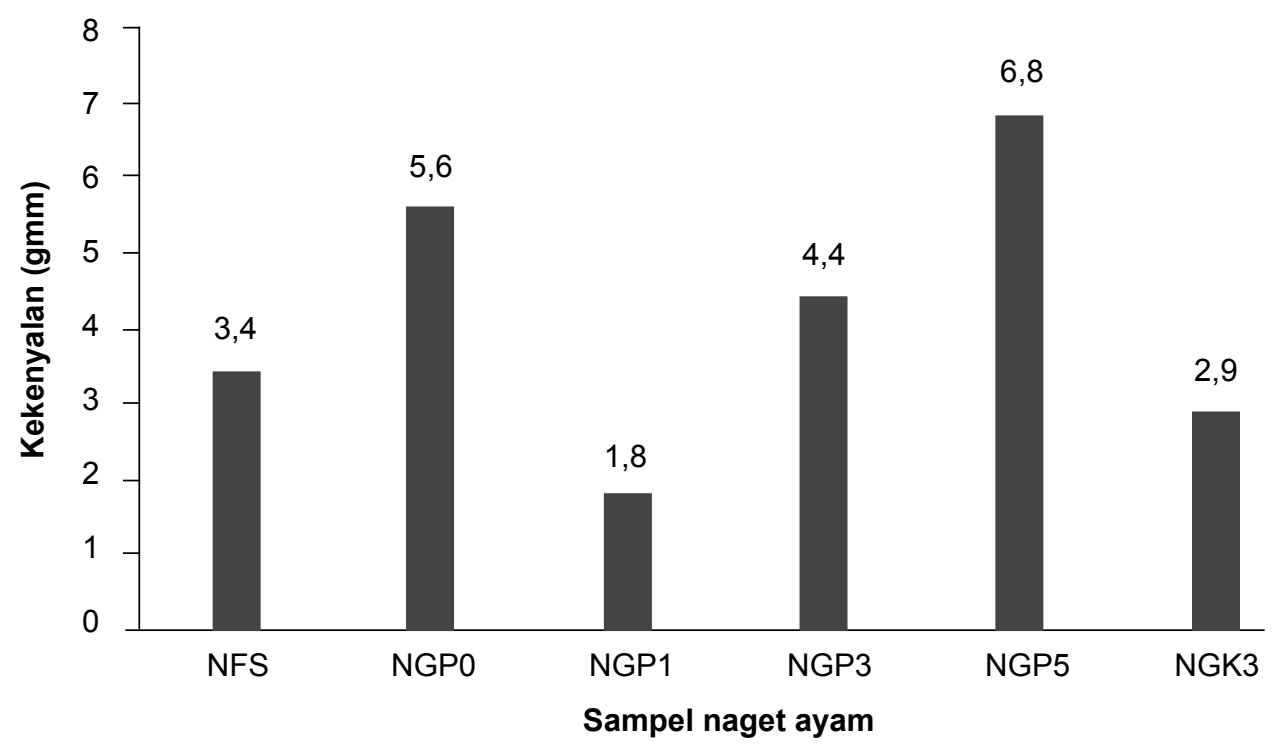

Gambar 1. Kekenyalan naget ayam yang dibuat pada beberapa formula (NFS =naget formula standar, $\mathrm{NGP0}=$ naget dengan pengurangan daging ayam tanpa substitusi glukomanan porang, NGP1=naget dengan substitusi glukomanan porang $1 \%$, NGP3=3\%, NGP5=5\%, NGK3=glukomanan konjak $3 \%$ )

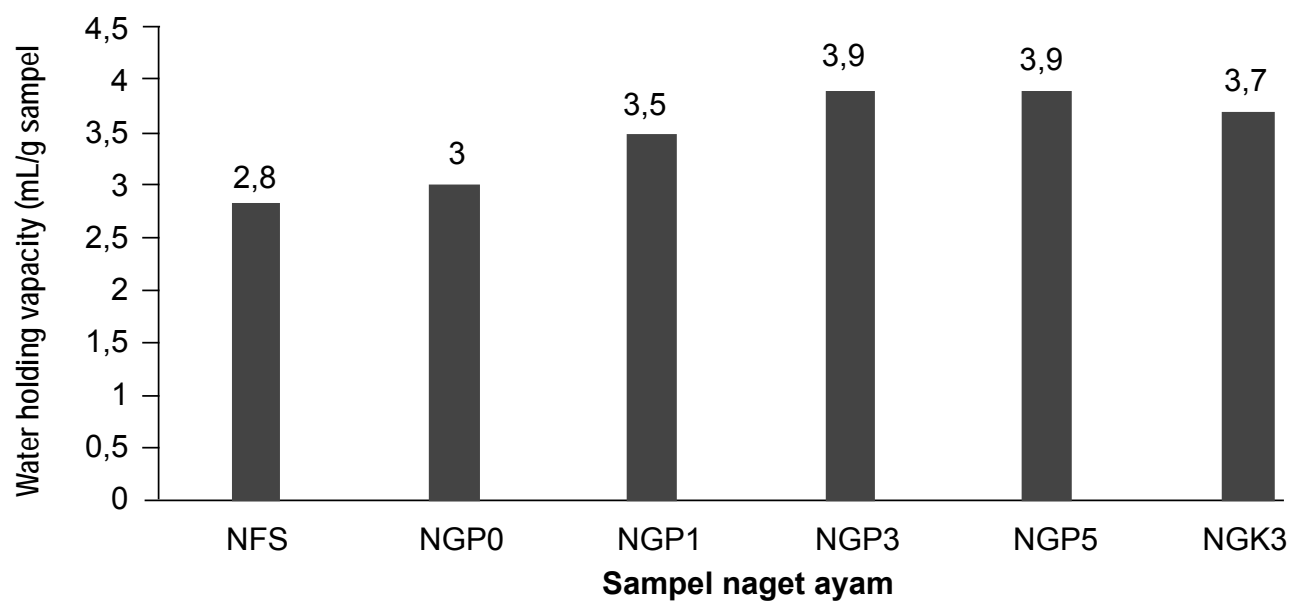

Gambar 2. Water holding capacity (WHC) naget ayam yang dibuat pada beberapa formula (NFS=naget formula standar, NGPO=naget dengan pengurangan daging ayam tanpa substitusi glukomanan porang, NGP1=naget dengan substitusi glukomanan porang 1\%, NGP3=3\%, NGP5=5\%, NGK3=glukomanan konjak $3 \%$ )

\section{Daya terima}

Hasil uji organoleptik sampel naget ayam dapat digunakan sebagai parameter daya terima pengembangan produk baru ini di masyarakat (Gambar 4). Secara umum, sampel NFS masih merupakan sampel dengan nilai penerimaan yang paling tinggi, dibuktikan dengan skor yang tinggi pada tiap atribut, baik warna, aroma, tekstur, rasa, maupun keseluruhan. Pada atribut warna, aroma, dan tekstur sampel NFS tidak berbeda nyata dengan NGP0 dan NGP1 $(p<0,05)$, sedangkan pada atribut rasa dan keseluruhan, NFS berbeda nyata dengan semua sampel yang disubstitusi $(p<0,05)$.

\section{BAHASAN}

\section{Kekenyalan}

Hasil analisis kekenyalan yang ditunjukkan Gambar 1 menunjukkan bahwa substitusi 


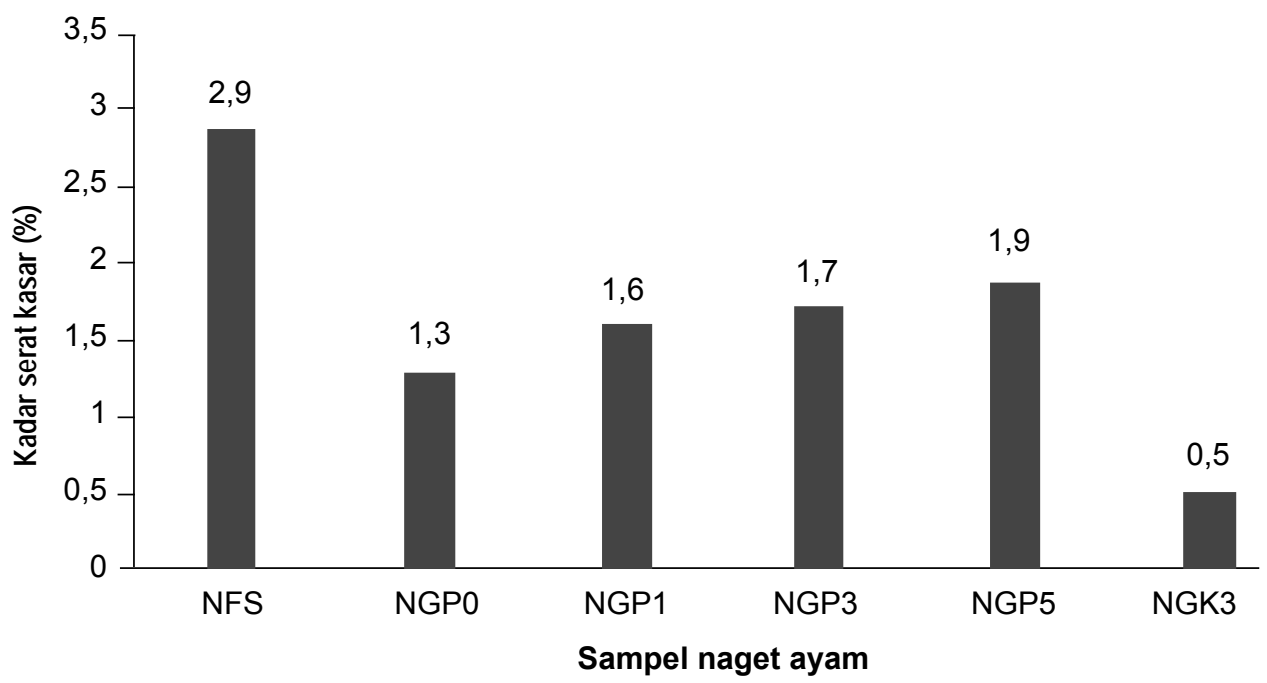

Gambar 3. Kadar serat kasar naget ayam yang dibuat pada beberapa formula (NFS=naget formula standar, NGP0=naget dengan pengurangan daging ayam tanpa substitusi glukomanan porang, NGP1=naget dengan substitusi glukomanan porang $1 \%$, NGP3=3\%, NGP5=5\%, NGK3=glukomanan konjak 3\%)

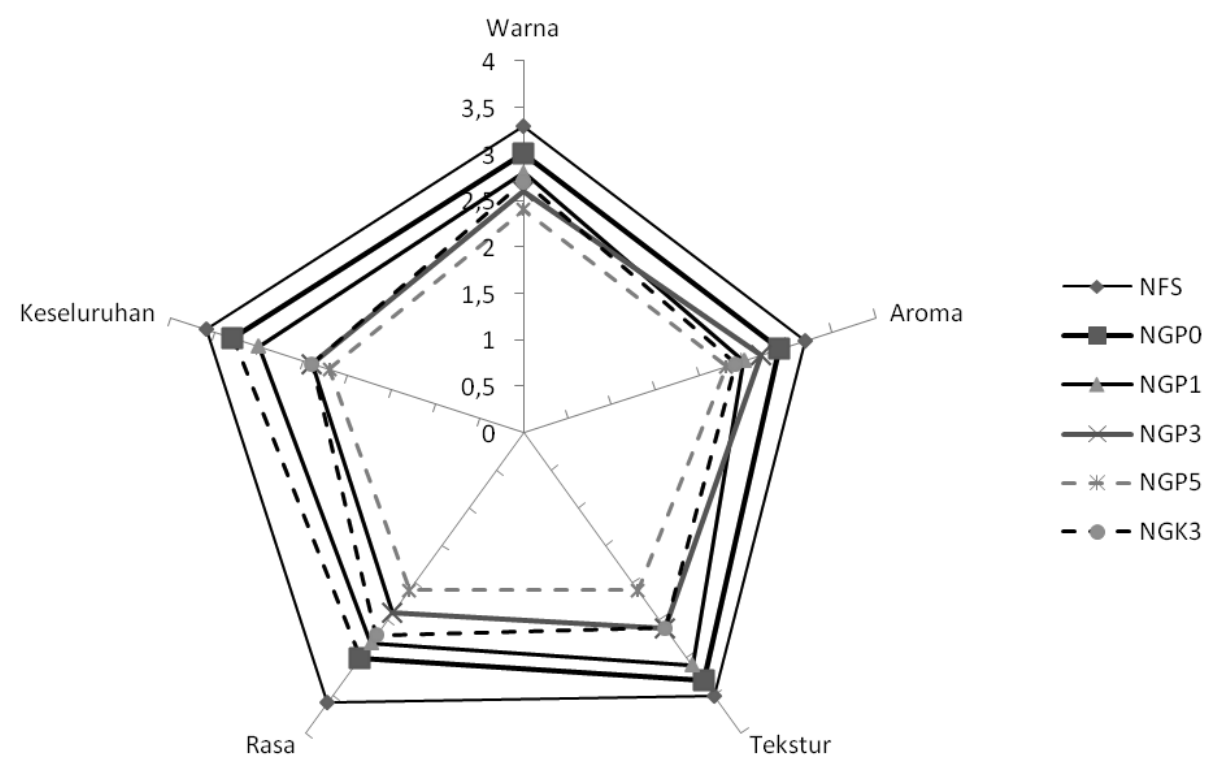

Gambar 4. Hasil uji organoleptik sampel naget ayam yang dibuat pada beberapa formula (NFS=naget formula standar, NGP0=naget dengan pengurangan daging ayam tanpa substitusi glukomanan porang, NGP1=naget dengan substitusi glukomanan porang $1 \%$, NGP3=3\%, NGP5=5\%, NGK3=glukomanan konjak $3 \%$ ). Skala yang digunakan $1=$ tidak suka, $2=$ =agak suka, $3=$ suka, $4=$ sangat suka

glukomanan ke dalam naget berpengaruh terhadap tekstur, terutama kekenyalan, Penelitian ini sejalan dengan penelitian yang dilakukan oleh Anggraeni dkk. (2014) (9) yang menyatakan bahwa semakin banyak tepung porang yang ditambahkan pada formula maka semakin banyak air yang terikat pada sosis maka kekenyalannya akan semakin kuat.
Naget merupakan produk daging-dagingan dengan ciri khas tekstur yang kenyal. Sifat ini terutama diperoleh dari protein miofibrial dari daging ayam yang ditambahkan. Protein miofibrial ini terdiri dari miosin dan aktin yang memiliki peran dalam pembentukan tekstur. Saat pemanasan, protein mengalami denaturasi sebagian kemudian 
diikuti agregasi permanen pada kepala miosin selama pembentukan jembatan disulfida dan transisi koil heliks pada ekor molekul. Hal ini menyebabkan terbentuknya cross-link 3 dimensi. Adanya penambahan bahan lain ke dalam produk daging akan mempengaruhi pembentukan gel 3 dimensi tersebut, salah satunya hidrokoloid (13).

Glukomanan merupakan hidrokoloid yang dapat berfungsi sebagai binding agents yang dapat mengikat komponen atau bahan baku yang digunakan dalam pembuatan naget ayam. Sifat hidrokoloid ini menyebabkan adanya perubahan sifat gel 3 dimensi. Pada penelitian ini, substitusi sejumlah daging ayam dengan glukomanan menyebabkan sifat kekenyalan makin kuat. Ditambahkan oleh Agustin (2011) (14), hidrokoloid menyebabkan kemudahan pembentukan gelatinisasi. Hal ini menjadikan kemudahan pembentukan crosslink 3 dimensi. Hasil review yang dilakukan oleh Sarteshnizi tahun 2015 diperoleh hasil bahwa pada beberapa produk daging yang disubstitusi dengan hidrokoloid, seperti glukomanan konjak, karagenan, pati, flaxseed gum, dan alginat diperoleh nilai kekenyalan yang lebih baik (13).

Selain dipengaruhi protein dalam daging, ternyata tekstur produk daging olahan juga dipengaruhi oleh lemak. Pada penelitian yang menggunakan bologna rendah lemak sebagai salah satu produk daging yang disubstitusi glukomanan konjak sebesar $1 \%$ menunjukkan tekstur yang sama dengan bologna yang tinggi lemak (13).

\section{WHC}

Berdasarkan Gambar 2 diketahui bahwa naget yang disubstitusi glukomanan memiliki WHC yang lebih tinggi dan berbeda nyata dibanding dengan formula standar $(p<0,05)$. Bila dibandingkan antarsampel yang disubstitusi glukomanan, ternyata tidak ada beda WHC pada berbagai konsentrasi glukomanan yang disubstitusi $(p>0,05)$. Dengan demikian, untuk tujuan komersialisasi yang mengarah pada perbaikan WHC, penambahan glukomanan $1 \%$ dapat dipilih.

Penelitian ini sejalan dengan yang dilakukan oleh Anggraeni dkk. (15) bahwa dengan peningkatan konsentrasi tepung porang dalam pembuatan sosis ayam, diperoleh daya ikat air atau menahan air yang lebih tinggi pula. Hal ini dapat disebabkan karakter glukomanan porang yang mampu mengikat air dalam jumlah besar (8), juga adanya ruang interstisial pada jaringan protein daging yang mampu mengikat air dan membentuk gel saat pendinginan (16).

Daya ikat air daging adalah kemampuan protein daging mengikat air di dalam daging, sehingga daya ikat air dapat menggambarkan tingkat kerusakan protein daging (17). Soeparno (1998) (18) menyatakan, bahwa daya ikat air (WHC) oleh protein daging dipengaruhi kekuatan dari luar, misalnya pemotongan daging, pemanasan, penggilingan, dan tekanan.

\section{Kadar serat kasar}

Pada penelitian ini, kadar serat kasar sampel yang disubstitusi glukomanan porang justru lebih rendah dibanding dengan formula standar (Gambar 3). Hal ini menandakan bahwa serat belum dapat ditingkatkan dengan adanya substitusi glukomanan sampai kadar $5 \%$. Hal ini sesuai dengan penelitian Bonato (2016) yang juga menambahkan serat gandum sampai kadar $2 \%$, namun belum dapat meningkatkan kadar serat dalam naget ayam (19).

\section{Daya terima}

Hasil penelitian ini membuktikan bahwa substitusi glukomanan porang pada naget ayam mempengaruhi sifat sensorisnya, bahkan cenderung berkurang, terutama rasa. Pada atribut sensoris lainnya, seperti warna, aroma, dan tekstur, substitusi glukomanan hanya dapat dilakukan sampai kadar 1\%. Di atas kadar tersebut, tingkat penerimaannya berkurang (Gambar 4). Terdapat beberapa komentar dari panelis yang menyatakan bahwa penurunan tingkat penerimaan ini disebabkan oleh tekstur yang makin keras. Di samping itu, adanya penurunan penerimaan aroma dan rasa disebabkan oleh sifat WHC yang tinggi dari glukomanan, sehingga air bebas menjadi sedikit yang menyebabkan zat penentu aroma dan rasa menjadi terikat di dalam bahan. Hal inilah yang menjadikan aroma serta rasa naget menjadi tertutupi. 
Hal ini sejalan dengan penelitian Anggraeni dkk. Pada tahun 2014 (15) yang menyatakan bahwa kenampakan sosis ayam mengalami penurunan semakin bertambahnya tepung porang dan tepung maizena yang ditambahkan. Penelitian Bonato (2016) juga mengungkapkan bahwa keberadaan serat dapat mengurangi tingkat penerimaan sensoris naget ayam (20).

\section{KESIMPULAN DAN SARAN}

Substitusi glukomanan ke dalam naget ayam belum dapat mempengaruhi kandungan seratnya, namun berpengaruh terhadap sifat fisik, yaitu menjadikan nilai WHC dan kekenyalan naget semakin tinggi.

Sebagai saran, untuk tujuan penambahan serat pada naget, dapat dilakukan penelitian pengembangan lain dengan penambahan bahan pangan mengandung serat tinggi lainnya. Hal ini diharapkan dapat menambah nilai fungsional dari naget ayam, terutama bagi kesehatan tubuh.

\section{RUJUKAN}

1. World health organization. World health statistics 2009. World health statistics. WHO Press; 2009.

2. Winarti S. Makanan fungsional. Yogyakarta: Graha IImu; 2010.

3. Silalahi J. Makanan Fungsional. Yogyakarta: Penerbit Kanisius (Anggota IKAPI); 2006.

4. Zhang $C$, Chen J, Yang F. Konjac glucomannan, a promising polysaccharide for OCDDS. Carbohydr Polym. 2014 Apr;104.

5. Davé V, McCarthy SP. Review of konjac glucomannan. J Environ Polym Degrad. Springer US; 5(4):237.

6. Mao C-P, Xie M-L, Gu Z-L. Effects of konjac extract on insulin sensitivity in high fat diet rats. Acta Pharmacol Sin. 2002 Sep;23(9):855-9.

7. Abrar Arifin M. Pengeringan umbi iles-iles secara mekanik untuk meningkatkan mutu keripik iles. Institut Pertanian Bogor; 2001.

8. Harmayani E, Aprilia V, Marsono Y. Characterization of glucomannan from
Amorphophallus oncophyllus and its prebiotic activity in vivo. Carbohydr Polym. 2014 Nov 4;112:475-9.

9. Amanah S. Kajian pembentukan gel glukomanan dari umbi iles-iles (amorphopallus oncophylus pr.) Hasil pengendapan glukomanan dengan menggunakan alkohol. Universitas Gadjah Mada; 1992.

10. Permadi SN, Mulyani S, Hintono A. Kadar serat, sifat organoleptik, dan rendemen nugget ayam yang disubstitusi dengan jamur tiram putih (plerotus ostreatus). J Apl Teknol Pangan. 2014;1(4):115-20.

11. Muchtadi T., Sugiyono. Petunjuk laboratorium bahan pangan. Bogor: Departemen pendidikan dan kebudayaan. Direktorat Jenderal Pendidikan Tinggi Pusat Antar Universitas Pangan dan Gizi. Institut Pertanian Bogor.; 1992.

12. Sudarmadji, S. BHS. Prosedur untuk uji analisi makanan dan pertanian. Yogyakarta: Liberty; 1997.

13. Sarteshnizi A, Hosseini H, Khaneghah M, Karimi N. A review on application of hydrocolloids in meat and poultry products. Int Food Res $\mathrm{J}$. 2015;22(3):872-87.

14. Agustin S. Efek polisakarida non pati terhadap karakteristik gelatinisasi tepung sukun. J Teknol Pertan Univ Mulawarman. 2011;7(1):28-35.

15. Anggraeni DA, Widjanarko SB, Ningtyas DW. Proporsi tepung porang (amorphophallus muelleri blume) : tepung maizena terhadap karakteristik sosis ayam. J Pangan dan Agroindustri. 2014;2(3):214-23.

16. Verbeken $D$, Neirinck $N$, Van Der Meeren $P$, Dewettinck K. Influence of K-carrageenan on the thermal gelation of salt-soluble meat proteins. Meat Sci. 2005 May;70(1):161-6.

17. Hartono E, Iriyanti N, Santosa RSS. Penggunaan pakan fungsional terhadap daya ikat air, susut masak, dan keempukan daging ayam broiler. J IIm Peternak. 2013;1(1):10-9.

18. Soeparno. Ilmu teknologi daging. Yogyakarta: UGM Press; 1998.

19. Bonato P, Perlo F, Fabre R, Teira G, Tisocco O, Gabriela Dalzotto M, et al. Effect of sodium 
chloride reduction and wheat fiber addition on chicken nugget quality. Br J Appl Sci Technol Pakistan Banat Univ Agric Sci Vet Med Rom. Adela Marcu Nadzirah Kamarul Zaman; 2016;17(3234):1-9.

20. Bonato P, Perlo F, Fabre R, Teira G, Tisocco O, Gabriela Dalzotto M, et al. Effect of Sodium
Chloride Reduction and Wheat Fiber Addition on Chicken Nugget Quality. Br J Appl Sci Technol Pakistan Banat Univ Agric Sci Vet Med Rom [Internet]. Adela Marcu Nadzirah Kamarul Zaman; 2016 [cited 2017 Mar 14];17(3234):1-9. Available from: http://www.sciencedomain.org/ review-history/16015 